\title{
— CONTEMPORARY PHONOLOGICAL THEORY AND COMMON PRONUNCIATION ISSUES
}

\author{
VIŠNJA JOSIPOVIĆ SMOJVER ${ }^{1}$ \\ Faculty of Humanities and Social Sciences \\ University of Zagreb
}

U ovom radu razmatra se uloga suvremene fonološke teorije u poučavanju engleske fonetike na sveučilišnoj razini. Pobliže, pokazuje se kako, nasuprot uvriježenom popularnom vjerovanju, nastava engleske fonetike za studente engleskoga jezika nema za cilj da se studente uči da engleski izgovaraju „kultivirano", što god to u današnje doba podrazumijevalo. Budući da sveučilišna izobrazba budućih stručnjaka za engleski jezik zahtijeva stjecanje uvida u prirodu izgovornih pojava, u ovom se radu pokazuje kako fonološka teorija može rasvijetliti neke praktične izgovorne probleme. To se čini pozivanjem na teorijske okvire poput grkljanske fonologije, teorije otvora, artikulacijske teorije te optimalnosne teorije, da bi se pokazalo kako podizanje razine fonološke osviješćenosti o izgovornim problemima može razviti senzibilitet za važna izgovorna pitanja.

Ključne riječi: fonološka teorija, izgovorne pojave, poučavanje engleske fonetike, fonološka osviješćenost.

\section{INTRODUCTION}

The present paper addresses two basic kinds of pronunciation issues that contemporary phonological theory can throw light on. One of them concerns a rather practical issue in mastering English pronunciation, namely, the apparent intelligibility of the English lyrics of popular songs and the way in which some theoretical phonological frameworks can account for this. The other one includes theoretical phonological issues which are generally useful in developing sensitivity to important English pronunciation features. The former is going to be analysed in connection with three popular songs (The Road to Mandalay, Budapest, and Sign of the Times) and with reference to the broad

1 Contact information: visnja.josipovic@zg.t-com.hr 
framework of Feature Geometry, in particular, the dimensional theory of laryngeal features, as in Iverson and Ahn (2007); the account of lenition processes as given by Gurevich (2011) or Ernestus (2011); Aperture Theory (Grijzenhout 1996, 2011), and Optimality Theory (McCarthy 2007, 2008).

As for the general theoretical issues that are of some interest in teaching English phonetics at university level, they are twofold. They include pronunciation features related to the typological prosodic differences between English and the students' first language, as well as some amusing, but nonetheless useful, theoretical phonological insights contributing to raising phonological awarenes, such as ludlings and expletive infixation.

\section{PRACTICAL ISSUES}

Concerning the practical issues related to English pronunciation, reference is going to be made to three popular songs, all of them number-one hits from the world's top charts. The first is the Robbie Williams 2001 hit, The Road to Mandalay. What initially drew the attention of the present paper's author to its lyrics was an informal survey carried out by Mateusz-Milan Stanojević (personal communication) among a group of Croats, including students and teachers from the Department of English, University of Zagreb. When asked to write down the refrain of the song, each of them responded by 'Pa ram pam pam pam pam pam pam', as opposed to the original refrain text of the lyrics offered on YouTube (https://genius.com), 'Bom bom bom ba da dup bom bom'.2 When the author of the present paper, who without hesitation would have responded in exactly the same way, checked the original lyrics in disbelief, there followed another shock: after 'Save me from drowning in the sea' what followed was 'beat me up on the beach', rather than 'pick me up on the beach', which any speaker of Croatian would probably have heard!

To account for this kind of misperception, contemporary phonological theory offers some interesting insights into the difference between aspiration languages and voicing languages within the broader framework of laryngeal phonology, which ultimately can be placed into a yet wider framework of feature geometry. In particular, reference should be made to the so-called dimensional theory of laryngeal features, as proposed by Iverson and Ahn (2007). These two authors account nicely for the true nature of the difference between aspiration languages and voicing languages.

The gist of their theory is that in aspiration languages, such as English and the majority of Germanic languages, voicing is not present in the phonological representation. That is, in these languages segments are unspecified for voicing. Rather, they are specified either for the feature 'spread glottis' [sg] or 'constricted glottis' [cg], which are seen as privative, unary, i.e., non-binary features. Under this approach voicing is seen as redundant in aspiration languages: in sonorants it is spontaneous, whereas in voiced obstruents, which are not specified as [sg], it is passive.

On the other hand, the category of voicing languages, for which Iverson and Ahn (2007) take French as an outstanding example, obviously includes languages like

2 https://genius.com/Robbie-williams-the-road-to-mandalay-lyrics [June 12, 2018] 
Croatian and Serbian as well. In these languages segments are specified for voicing, but not for the other two laryngeal features, [sg] and [cg].

Although it is indisputable that the contrast between voiced and voiceless consonants does exist in English, in the dimensional theory this is interpreted as a surface phonetic contrast on the post-lexical level, functioning to enhance the truly phonologically relevant contrast between the gestures of opening and closing the glottis. Phonetically, the feature of spread glottis is realised as audible breath, i.e., aspiration in the right context, where the contrast needs to be enhanced, which is the foot-initial position in English (e.g. 'a tissue', as opposed to 'at issue', to quote the famous phonology-textbook example).

Bearing all this in mind, let us return to our initial issue of the misperception of voicing in English by speakers of Croatian and explain why it happens. In short, the two languages are typologically different with respect to the status of voicing. In English, as opposed to Croatian, voicing is a redundant feature, which is only passive in voiced obstruents, such as the /b/ in the examples from the Robbie Williams song referred to above. The phonetic manifestation of this difference between the two languages under consideration is the misleading difference in the voice onset time.

Taking all this into consideration, it is no surprise then that Jenkins (2000) includes aspiration among features of English pronunciation that belong to the so-called Lingua Franca Core, i.e., those that are likely to be associated with the international unintelligibility of English. This also explains the numerous jokes and anecdotes in Croatian based on situations of misunderstandings between Germans and croats, like the one involving the German word 'danke' ('thank you') misperceived as 'tanke' (meaning 'thin' in Croatian).

Perhaps another point to note in connection with the refrain of The Road to Mandalay concerns the flap, indicatively spelled as $\boldsymbol{d}$ in the English version ( ${ }^{\prime} . . . b a \boldsymbol{d} a$ dup...') and as $r$ in its (roatian counterpart. It is the underlying [cg] coronal stop, which is phonetically not only passively voiced, but also lenited (weakened) in the lenis intervocalic surroundings. However, this issue of lenition brings us to the next example of song lyrics misperception discussed in the present context.

In George Ezra's 2014 hit Budapest (https://genius.com)3 ${ }^{3}$ there is another example of the same kind of lenition when the /t/ of 'it' in 'I'd leave it all' and 'I'd lose it all' is typically perceived by Croatian speakers as/d/, within the wider context of the stretches misperceived as [aI divi 'do:] and [a , du:zi 'do:]. Here one can observe extreme cases of lenition affecting the coronal lateral /I/, a type of segment which is really special in phonological theory in that there are apparently more controversial and unresolved issues about it than for any other segment (cf. Yip 2011).

All the major theoretical frameworks which have provided some interesting insights into the nature of this kind of lenition in one way or another treat sonority as an inherently gradual feature, as opposed to the majority of other segmental features, which are treated as non-gradual, i.e., either binary or monovalent. One of them is Aperture Theory, as set out by Grijzenhout (1996). The way in which the cases of lenition under consideration are analysed in this theory is to operate with nodes of aperture

3 https://genius.com/George-ezra-budapest-lyrics [June 12, 2018]. 
(ranging from $A_{0}$ to $A_{\max }$ ) within the feature geometry tree to account for potentially gradual features, such as sonority or nasality. Lenition processes like those affecting the English lateral /// in the example at hand, just like the opposite fortition processes are then interpreted as delinking nodes representing particular degrees of opening, or, respectively, segments docking onto nodes representing certain aperture degrees.

Likewise, authors like Gurevich (2011), for example, or Ernestus (2011), explicitly operate with a hierarchy of lenition expressed on a scale ranging from geminates at the one end to zero, corresponding to the loss of a segment. This latter extreme would correspond to the complete loss of the /// in the examples at hand, [a ${ }_{\text {I }}, d_{I V}{ }^{\prime}{ }^{\prime} d o:$ and [a du:zi ' $\mathrm{d}$ s:], where the /I/ of 'leave' and 'lose' are completely lost, whereas the degree of the lenition of the final / $/ /$ of 'all' is disputable and variable, depending on the listener: it can be anything ranging from a 'dark', velarised [ 1 ], through the fully vocalised one, [u], down to the complete loss, i.e., zero, as in 'leave' and 'lose'.

Finally, Optimality Theory with Candidate Chains, OT-CC, as in McCarthy (2007) has its own way of dealing with what is perceived as lenition processes - postulating a level of candidate chains in which each candidate is exactly by one grade more harmonic than the previous one.

The last song which will be referred to here is Harry Styles' 2017 number one in the UK, Sign of the Times (https://genius.com) ${ }^{4}$. The focus will be on the reason that someone, especially a speaker of a pitch-accent language, is likely to interpret 'the bullets' as sung in the example at hand as a separate word, something like 'topolits'.

What elegantly explains this are two 0T constraints, working to the same effect here. They are most blatantly violated here by the unfortunate match of the melody and the text, when the melody goes sky-high on the definite article. One of the constraints under consideration is known as R00TING (cf. McCarthy 2008). It generally requires the prosodic prominence of lexical morphemes, i.e. roots. In the analysis of tone languages there is a similar constraint, in fact somewhat broader in scope, requiring the linking of $\mathrm{H}$ tones to prosodically or morphologically prominent positions. Needless to say, even though English is not a tone language, the extremely high pitch on the definite article for a speaker of a pitch-accent language definitely equals $\mathrm{H}$ tone, which in its turn equals accent, and a sequence perceived like/'topolits/ equals a prosodic and morphological word!

\section{GENERAL PRONUNCIATION ISSUES}

In terms of other phonological insights useful for teaching English phonetics to speakers of pitch-accent languages, a special place belongs to the OT account of Neoštokavian pitch-accent prosody as given by Zec (1999). Although as a speaker of Serbian the author naturally refers to Serbian, it should be noted that this kind of theoretical account is applicable to Croatian as well, as these two cognate languages belong to the same category in terms of prosodic typology.

In this context we may return to the point made in connection with the unintelligibility of 'the bullets' in Signs of the Time. What throws additional light on the

4 https://genius.com/Harry-styles-sign-of-the-times-lyrics [June 12, 2018] 
issue is one of the crucial ideas of the account of Neoštokavian provided by Zec (1999), namely, that of tonal feet. When it receives a high tone, a syllable acquires the status of a tonal foot (as opposed to a metrical foot), and within the framework of this very insightful account, Neoštokavian prosody is explained in terms of a complex interaction of OT constraints characterising trochaic rhythm and pitch-accent prosody.

This kind of approach again clears up a number of practical pronunciation issues in the languages concerned, such as the misperception of song lyrics in $\mathrm{L}_{1}$, analogous to those discussed above in connection with teaching English phonetics. It also helps to understand the awkward and unnaturally-sounding accentual patterns in $\mathrm{L}_{1}$ which are commonly heard in the media, as well as patterns behind $\mathrm{L}_{1}$ prosody acquisition, as discussed in Josipović Smojver (2003; 2017), to name a few. Needless to say, specialists in a foreign language are expected to have some basic insights about their own language, as well as to be able to describe their native language in the first place.

Finally, mention should be made at this point of some amusing theoretical insights provided by contemporary phonological theory, which can teach us about various English pronunciation phenomena. Among them are the so-called ludlings (also known as language games, secret languages). There are lots of various ludlings, based on different languages, including English (e.g. Pig Latin, Ubbi-Dubbi, Schmanguage, Shizzolation, Spaka, Homeric) and Croatian (e.g. Jepezipik, the Croatian version of the internationally known Parrot Language), as well as those based on other, better or lesser known world languages. ${ }^{5}$ The morphoprosodic templates used in the word formations of these secret languages can teach a student of English phonetics a lot about syllable structure - both universal and language-specific aspects of it. Ludlings are also instructive in connection with the role of prosodic domains for expressing pronunciation rules and regularities. A case in point would be hypocoristic formation, which generally follows morphoprosodic templates comparable to those of ludlings in both English and Croatian.

The prosodic domains commonly used in ludling word formation include not only the syllable with its constituents,which are important, for example, in Pig Latin and Jepezipik, but also the foot, mentioned above in connection with the English aspiration rule. It is precisely the foot that plays the crucial role in Homeric, described by Vaux (2011: 741). This brings us to the other example of how contemporary phonological theory can throw light on pronunciation phenomena in an amusing way. Just like the language game of Homeric, the English phenomenon of expletive infixation relies on the foot as the relevant analytical entity in phonology, following the principle of inserting the 'dirty-word' infix consisting of a foot, i.e. a sequence of a stressed and an unstressed syllable. Typical expletive infixes following this template would be bloody, or fucking, for example, which are inserted between the feet of the original, startingpoint words of 'regular' English, resulting in expletive forms like Ala-bloody-bama for Alabama. (cf. McCarthy 1982). An analogous Croatian procedure is discussed in Josipović Smojver (2017) with reference to the example Erasmus - vražji - ugovor.

5 Elaboration of the topic, as well as detailed references are given in Josipović Smojver (2017). 


\section{CONCLUSION}

By way of conclusion, it turns out that constant references to contemporary phonological issues are necessary in teaching English at university level. Nowadays there are influential linguistic theories and phonological models that no longer even see phonology and phonetics as separate components, cases in point being Articulatory Theory, as in Browman and Goldstein (1992) or Zsiga (2018), as well as feature theories focusing on the gradient nature of certain phonological features, such as Ernestus (2011) or Gurevich (2011).

It seems indisputable that phonological insights into the nature of pronunciation phenomena develop sensitivity to pronunciation issues. Provided that such an attitude is encouraged in phonetics teaching at university level, the ultimate outcome is going to be not only a more cultivated English pronunciation among future specialists in the English language, but also, notably, a greater degree of effectiveness in cultivating others' English pronunciation in the broadest sense.

\section{REFERENCES}

Browman, C. and L. Goldstein. 1992. Articulatory Theory: An overview. Phonetica 49, 155-180. Ernestus, M. 2011. Gradience and Categoricality. In M. van Oostendorp, C. Ewen, E. Hume and K. Rice (eds.) The Blackwell Companion to Phonology. Vol. IV, Phonological Interfaces. Chichester, UK: Wiley-Blackwell, 2115-2136.

Grijzenhout, J. 1996. Consonant weakening processes and Aperture Theory. Toronto Working Papers in Linguistics 15, 105-124.

Grijzenhout, J. 2011. Consonant Mutation. In M. van Oostendorp, C. Ewen, E. Hume and K. Rice (eds.) The Blackwell Companion to Phonology, Vol. III, Phonological Processes. Chichester, UK: Wiley-Blackwell, 1537-1558.

Gurevich, N. 2011. Lenition. In M. van Oostendorp, C. Ewen, E. Hume and K. Rice (eds.) The Blackwell Companion to Phonology, Vol. III, Phonological Processes. Chichester, UK: Wiley-Blackwell, 1559-1575.

Iverson, G. K. and S. C. Ahn. 2007. English Voicing in Dimensional Theory. Language Sciences, May, 29 (2.3), 247-269. doi: 10.1016/j.langsci.2006.12.012.

Jenkins, J. 2000. The Phonology of English as an International Language: New Models, New Goals. Oxford: Oxford University Press.

Josipović Smojver, V. 2003. Ema, Nina i Emanina: analiza slučaja blizanačkog govora. Govor XX, 1-2, 169-179.

Josipović Smojver, V. 2017. Suvremene fonološke teorije. Zagreb: Ibis grafika.

McCarthy, J. 1982. Prosodic Structure and Expletive Infixation. Language 58 (3), 574-590.

McCarthy, J. 2007. Hidden Generalizations: Phonological opacity in Optimality Theory. London: Equinox.

McCarthy, J. 2008. Doing Optimality Theory: Applying Theory to Data. Maiden, MA: Blackwell.

Vaux, B. 2011. Language Games. In J. Goldsmith, J. Riggle i A. C. L. Yu (eds.) The Handbook of Phonological Theory. $2^{\text {nd }}$ edition. Chichester, UK: Blackwell Publishing Ltd., 722-750. 
Yip, M. 2002. Tone. Cambridge, UK: Cambridge University Press.

Yip, M. 2011. Lateral Consonants. In M. van Oostendorp, C. Ewen, E. Hume and K. Rice (eds.) The Blackwell Companion to Phonology, Vol. I, General Issues and Segmental Phonology. Chichester, UK: Wiley-Blackwell, 730-756.

Zec, D. 1999. Footed tones and tonal feet: rhythmic constituency in a pitch-accent language. Phonology 16, 225-264.

Zsiga, E. C. 2018.The Phonetics and Phonology of English Casual Speech: Learning from L2 Learners. Paper presented at The Fourth Belgrade International Meeting of English Phoneticians (BIMEP 2018), English Department, Faculty of Philology, University of Belgrade, 30-31 March 2018.

\section{SUMMARY}

\section{CONTEMPORARY PHONOLOGICAL THEORY AND COMMON PRONUNCIATION ISSUES}

This paper discusses the role of contemporary phonological theory in teaching English phonetics at university level. In particular, it is shown how, contrary to common popular belief, teaching English phonetics to students of English is not really about teaching them to pronounce English 'properly', whatever the idea of 'proper' English pronunciation might nowadays imply. As university education of future specialists in the English language requires gaining insights into the nature of pronunciation phenomena, it is argued that phonological theory can throw light on some practical pronunciation issues. This is done with reference to theoretical phonological frameworks, such as Laryngeal Phonology, Aperture Theory, Articulatory Theory and Optimality Theory, in order to show how raising phonological awareness about pronunciation phenomena can develop sensitivity to important pronunciation issues.

KEYWORDS: phonological theory, pronunciation issues, teaching English phonetics, phonological awareness.

ARTICLE INF0:

Original research article

Received: June 14, 2018

Revised: February 6, 2019

Accepted: February 9, 2019 